\title{
Risk assessment of wildlife-watching tourism in an important endangered loggerhead turtle rookery
}

\author{
Adolfo Marco ${ }^{1,2, *}$, Samir Martins ${ }^{2}$, Alejandro Martín-Rábano ${ }^{2}$, Sonia Lopes ${ }^{3}$, \\ Leo J. Clarke ${ }^{4}$, Elena Abella ${ }^{1}$ \\ ${ }^{1}$ Estación Biológica de Doñana, CSIC, C/ Américo Vespucio s/n, Sevilla 41092, Spain \\ ${ }^{2}$ BIOS.CV, C/ Sta Isabel s/n, Sal Rei, 5211 Boa Vista, Cabo Verde \\ ${ }^{3}$ Direcção Geral do Ambiente, Cha d' Areia s/n, Praia, 332A Santiago Island, Cabo Verde \\ ${ }^{4}$ School of Ocean Sciences, Bangor University, Menai Bridge LL59 5AB, UK
}

\begin{abstract}
Wildlife-watching tourism is a non-exploitative activity that can contribute to sustainable economic development of coastal communities. However, it is important to assess the potential impact and implement best practices to mitigate any negative effects of such tourism. We studied this issue on Boa Vista (Cabo Verde), which supports around $60 \%$ of nesting activity of one of the most endangered loggerhead turtle rookeries globally. Between 2013 and 2016, authorized turtle watching involved 4942 tourists, generating a mean annual direct income of >USD 289000 and the direct creation of $>250$ jobs. On João Barrosa beach, which supports around $20 \%$ of nests and $48 \%$ of turtle-watching activity on the island, we tested the influence of turtle watching on nesting behavior, reproduction and nest-site fidelity. Nesting females observed by tourists spent significantly less time on nest-camouflaging behavior, although all other phases of nesting were unaffected. There were no statistically significant differences between the re-nesting frequency of females watched $(n=187)$ and non-watched $(n=972)$ by tourists. We found no evidence that the current turtle-watching intensity has an effect on turtle reproduction. Turtle poaching remains a severe threat on beaches with no turtle watching, although it has strongly decreased on beaches with tourist visits. We suggest tour guides follow best practice guidelines to minimize disturbance, specifically retreating from the immediate vicinity of a female during nest camouflaging to mitigate the observed impact.
\end{abstract}

KEY WORDS: Sea turtles - Wildlife tourism - Turtle watching - Cabo Verde - West Africa · Risk assessment

\section{INTRODUCTION}

Tourism is a dynamic and growing sector of the global economy and makes a significant contribution to the socio-economic development of many coastal areas. In 2019, the number of international tourist arrivals grew globally by $4 \%$ and reached 1.5 billion (UNWTO 2020), although economic growth driven by tourism may result in problems and conflicts associated with the uncontrolled flow of people, leading to a loss of cultural and moral values, economic inflation and environmental de-

\footnotetext{
*Corresponding author: amarco@ebd.csic.es
}

gradation. Furthermore, disparity may exist in how the revenue generated is divided between large tourism companies and the local communities in the countries within which they operate (Fennell 2006). The United Nations promotes sustainable tourism as economic development that can contribute to the pillars of sustainability (UNWTO 2020). Within this context, the concept of ecotourism aims to make compatible the sustainable development of local communities and the maintenance of pristine and undisturbed natural areas of biodiversity (Wunder 2000).

(C) The authors 2021. Open Access under Creative Commons by Attribution Licence. Use, distribution and reproduction are unrestricted. Authors and original publication must be credited. 
Wildlife tourism is reliant on biodiversity and provides economic incentives for conservation (Winterbach et al. 2015) across a wide range of habitats (Stewart et al. 2005, Howell et al. 2015, Malik \& Bhat 2015, Santarém \& Paiva 2015). Globally, protected areas (PAs) receive roughly 8 billion visits annually, with an approximate income of USD 600 billion in direct in-country expenditure and USD 250 billion in consumer surplus (Krüger 2005, Balmford et al. 2015). Many countries have invested heavily in wildlife tourism and rely on the sector to support both long-term wildlife conservation and sustainable development in local communities (Weaver 1999, Hearne \& Salinas 2002, Wilson \& Tisdell 2001, Krüger 2005, Rathnayake 2016). In the marine environment, wildlife-watching tourism focuses mainly on cetaceans, sharks, rays, penguins, and sea turtles (Stewart et al. 2005, Topelko \& Dearden 2005, Gallagher \& Hammerschlag 2011, Kessler \& Harcourt 2013, Rathnayake 2016), and in many cases is conducted in areas in which numbers of these animals have been reduced by illegal hunting by local coastal communities, leaving them at risk of extinction (Tisdell \& Wilson 2001, Parsons et al. 2003, Rathnayake 2016). There is therefore a need to understand the impacts of wildlife watching on such threatened populations.

In the case of sea turtles, the majority of watching activity occurs in the largest turtle rookeries around the word (Johnson et al. 1996, Poland et al. 1996, Marcovaldi \& Marcovaldi 1999, Godfrey \& Drif 2001, Wilson \& Tisdell 2001, Downie et al. 2003, Meletis \& Harrison 2010, Rathnayake 2016). Some turtle watching occurs in the water, through direct observation from a boat (Howell et al. 2015, Schofield et al. 2015, Papafitsoros et al. 2020), or diving and snorkeling in shallow coastal areas (Landry \& Taggart 2010, Papafitsoros et al. 2020), although the majority occurs on nesting beaches. In many developing countries, where turtle rookeries are often found, turtles are still traditionally harvested as a source of food and traditional medicine (Loureiro \& Torrão 2008, Humber et al. 2014, Martins et al. 2015). As most species of sea turtle are listed by the IUCN as endangered, and some populations considered under critical risk of extinction (IUCN 2020), observation by tourists may therefore offer an alternative to their exploitation and contribute to their conservation. In this context, tourist visits to watch turtles nesting on the beach can be an opportunity to reconcile the sustainable development of local communities in developing countries and the conservation of biodiversity. In such countries, turtle watching can generate signifi- cant income and high-quality employment (Marcovaldi \& Marcovaldi 1999, Wilson \& Tisdell 2001, Meletis \& Harrison 2010, Pegas \& Stronza 2010, Rathnayake 2016). Recognition of the fact that turtles are worth more alive than dead can generate social and cultural change in local communities, reducing the exploitation of turtles and facilitating a more sustainable relationship with local biodiversity.

Nonetheless, despite these benefits, several important questions arise alongside the development of ecotourism and wild turtle watching by tourists. Is this activity really sustainable? Does turtle watching adversely affect turtles? How, where and when should these visits be conducted to minimize such effects? What should the regulations and limits to such activities be to maintain healthy turtle populations? Finally, can endangered turtle populations be used as a resource for ecotourism and wildlife watching without compromising their recovery?

To contribute to a better understanding of the sustainability of turtle-watching activity, we carried out a study on the island of Boa Vista, Republic of Cabo Verde. The island hosts around $60 \%$ of all nesting activity of the endangered Northeast Atlantic loggerhead Caretta caretta population (Wallace et al. 2011, Marco et al. 2012, Casale \& Marco 2015). Sea turtles are a significant part of Cabo-Verdean marine heritage and have traditionally been exploited economically (Loureiro \& Torrão 2008). On all islands of the archipelago, people from coastal communities have traditionally used sea-turtle meat and by-products for seasonal subsistence, traditional health, aphrodisiac purposes and handcrafts (Loureiro \& Torrão 2008, Martins et al. 2015). Currently, tourism is one of the main sectors of economic development in Cabo Verde, comprising $20.1 \%$ of GDP and generating an average of 36000 jobs. Tourism generates approximately USD 0.5 million annually, comprising approximately $22 \%$ of the Cabo Verde economy (INE 2019). Organized turtle watching by tourists started on Boa Vista between 2000 and 2005, initially with $<500$ tourists participating per year, and has grown continuously to >10 000 tourists per year in 2018 and 2019 .

Within this context, the main goal of this study was to assess the interactions between turtle watching and the ongoing conservation efforts of an endangered loggerhead turtle population. Our main objectives were to (1) describe the development and distribution of turtle watching on Boa Vista; (2) assess the relationship between turtle-watching activities and nest abundance, the level of poaching of females, female nesting behavior, clutch size and female nestsite fidelity on the beach; and (3) identify a scientific 
basis to inform best practice guidelines for turtle watching to minimize any negative impacts and ensure that turtle watching is compatible with the sustainable development of the coastal communities.

\section{MATERIALS AND METHODS}

The study took place on Boa Vista $\left(16.15^{\circ} \mathrm{N}\right.$, $22.80^{\circ} \mathrm{W}$ ), Republic of Cabo Verde, western Africa (Fig. 1). The coastline of the island is approximately $130 \mathrm{~km}$ long, of which $65.6 \mathrm{~km}$ is sandy beach. The eastern half of the island is protected and comprises the Sea Turtle Natural Reserve (STNR), the Park Natural of North (PNN) and Boa Esperança Natural Reserve (BENR) designations (Fig. 2). These 3 PAs areas host the vast majority of loggerhead turtle nesting activity on the island (Marco et al. 2012). Together with Sal, Boa Vista is one of the main islands of the archipelago that has supported the development of mass tourism (INE 2019). Due to the abundance of pristine sandy beaches, tourism has developed rapidly on these 2 islands, which receive around 1500000 European tourists annually (INE 2019). On Boa Vista, tourist accommodation capacity has increased from 1476 and an occupancy rate of $36.2 \%$ in 2006, to 6231 and an occupancy rate of $82.0 \%$ in 2016. Tourism infrastructure is largely located in the western half of the island where turtle

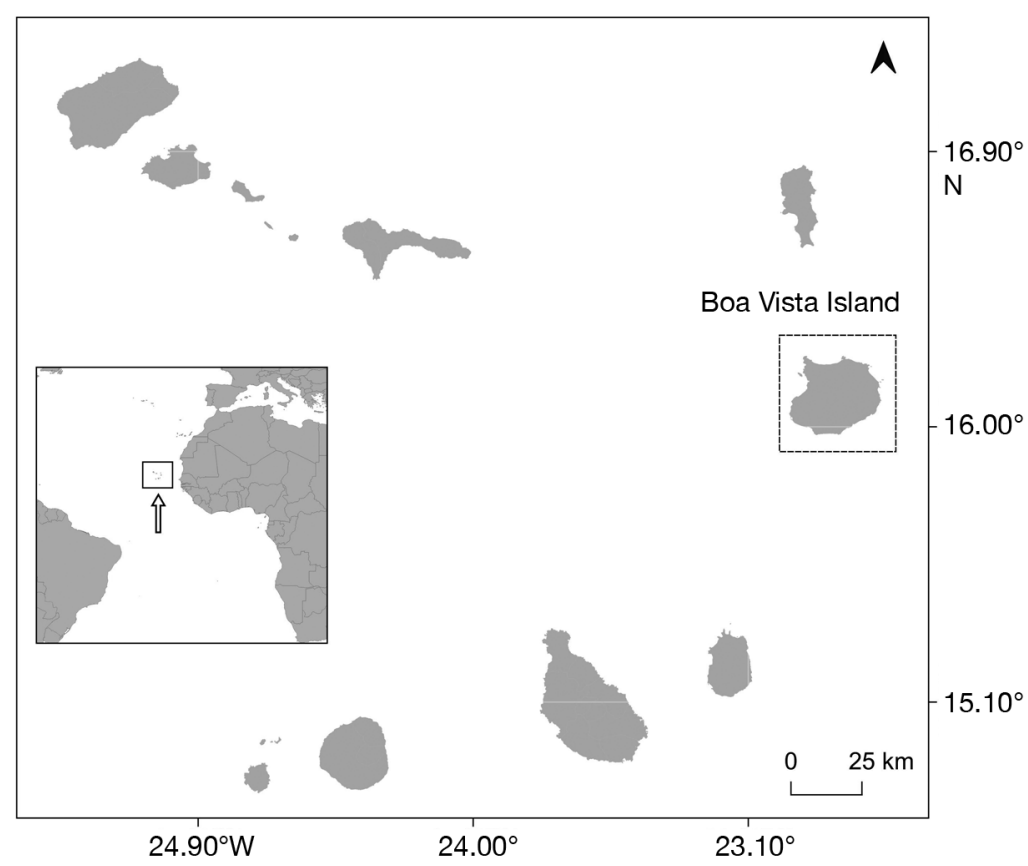

Fig. 1. Cabo Verde archipelago off West Africa, and the island of Boa Vista nesting is very scarce, with $<6 \%$ of nests laid on this part of the island every year.

\subsection{Turtle watching}

Information on tourism activity and turtle watching in particular was obtained from unpublished reports by the National Institute of Statistics of Cabo Verde (INE) and the Office of Protected Areas of Boa Vista. In addition, 434 turtle-watching tours were monitored directly on the beaches of João Barrosa $(5 \mathrm{~km}$ length; $16^{\circ} 2^{\prime} \mathrm{N}, 22^{\circ} 45^{\prime} \mathrm{W}$ ) (Fig. 2) across 4 nesting seasons (2013-2016). These beaches are located within the STNR (Fig. 2), which is also a Ramsar site (Curral Velho ID: 1575), and support the highest loggerhead nesting density (Marco et al. 2012; our Table 2) and are the most visited for turtle watching (see our Table 1) on Boa Vista. An official permit to conduct these studies was provided by the Environmental Directorate and the Office of Protected Areas of Boa Vista.

The Office of Protected Areas issued either daily or seasonal permits to tour operators for turtle-watching visits (for 1 single site or for several sites) from July 15 to September 30 each year, from 2013 to 2016 . Copies of these permits, or the details of them, were provided by tour operators for the present study. The compliance of each turtle-watching visit to the guidelines approved and provided by the Office of Protected Areas was assessed and the behavior of guides and tourists around the turtles was recorded. Permits authorize guides to visit a given beach to conduct a turtle-watching tour with tourists, although no specific site or beach sector is specified. Groups usually go directly to the beach areas that support a high density of nesting females, which is generally consistent between years, and walk along the beach until they encounter a nesting turtle. In most cases, this occurs within the first $200 \mathrm{~m}$ of the beach, although groups may occasionally walk up to $1 \mathrm{~km}$ along the beach.

Each turtle-watching tour arrives at the beach at the beginning of the night and waits until the ranger finds a turtle nesting. During that time, the guide usually gives some information to tourists about sea turtle biology and conservation. When the ranger finds a 


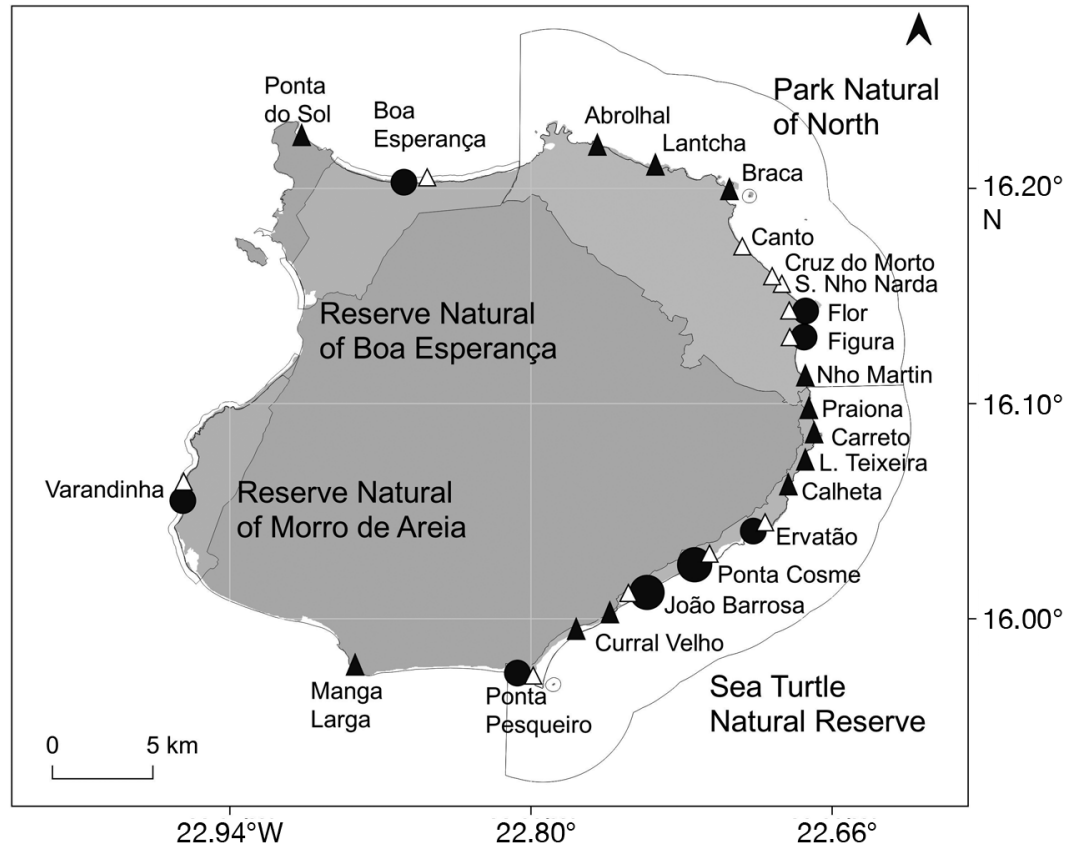

Fig. 2. Boa Vista with the limits of the terrestrial and marine protected areas, and our study beach, João Barrosa. Black circles: main turtle-watching locations; black triangles: beaches with higher current hunting pressure on female loggerhead turtles; white triangles: beaches where female hunting pressure was high in the past but is currently very low or null. Source: Ministry of Environment Housing and Spatial Planning, Cabo Verde ogy consistent with that used by NGOs across the entire island. Data were collected separately from beach sectors with and without turtlewatching tours. These tours started in 2007 (see Fig. 3), and were conducted on the same sections of the beach throughout the period until 2016. Daily beach patrols were conducted from mid-June to mid-October by experienced researchers, with assistance from volunteers. All nests, tracks, carcasses, or signs of poached females were recorded. To detect poached females, the entire length of each turtle crawl on the beach was monitored. Any tracks that did not end at the shoreline and that had no signs of a turtle, dead or alive, or of hunting/ slaughter in the nesting area and immediate vicinity, were considered to represent poached females (Marco et al. 2012). Data from João Barrosa beach were collected personally by the authors as part of a BIOS.CV NGO project. turtle starting to nest, the guide is informed, who goes with the tourists toward the turtle. The tourists observe the turtle from behind at a distance of 2-3 $\mathrm{m}$. The guides usually illuminate the nest hole to let the tourists watch the egg-laying process. The guides usually provide some explanations. When the turtle finishes nesting and returns to the water, the visit finishes and the tourists leave the beach.

\subsection{Nest abundance and poaching of females}

For the 4 nesting seasons across 2013-2016, field data on the abundance and distribution of loggerhead turtle nests and hunted females across the entire island of Boa Vista were obtained from the National Directorate of the Environment of Cabo Verde through the Office of Protected Areas. These data were collected by NGOs in ongoing monitoring programs conducted across the island (Associação Varandinha, Cabo Verde Natura 2000, Fundação Tartaruga and BIOS.CV), and were obtained as total values for each beach across the island.

On João Barrosa beach specifically, data were collected for the period 2007-2016, following methodol-

\subsection{Nesting behavior, clutch size and nest-site fidelity}

Data on female nesting behavior were collected from 76 female loggerhead turtles on João Barrosa between July and August 2016. Twenty-nine of these turtles were controls (C), with no direct human interaction during the whole nesting process. An experienced research team leader, assisted by 2-3 volunteers, observed 35 turtles, following the standardized protocols of the national monitoring program. These turtles are referred to as monitored (M) turtles. Finally, 12 females were watched by a group of tourists (T) led by an experienced guide from a local tour operator. All behavioral observations were made before 23:30 h, as all turtle-watching tours are typically conducted before that time.

During these observations, the nesting process was divided into the following 6 consecutive phases: (1) the ascent, from when the turtle first emerges from the water, including the crawl up the beach and nest site selection, ending when the turtle begins to dig the body pit; (2) the digging phase, which ends when the female finishes the nest chamber and the cloaca is extended; (3) the egg-laying phase, comprising the 
entire egg-laying process until the last egg is laid and the cloaca is retracted; (4) The nest-covering phase using the rear flippers, ending when the female starts to push sand backwards with the front flippers; (5) the camouflage phase, that ends when the female finishes camouflaging the nest and begins her descent from the nest; and finally, (6) the descent phase, ending when the female reaches the shoreline. The duration of each of these stages was recorded to the nearest second by an experienced observer hidden in the dark at a prudent distance from the turtle, using a stopwatch. The observer never interacted with the turtle or the people observing or monitoring the turtle. In the absence of moonlight, the observer used a red light to record data and a set of night vision binoculars (Bushnell $2 \times 24 \mathrm{~mm}$ NightWatch) to observe the turtle. The only person in the proximity of the control turtles was the observer who remained hidden and never interacted with the turtle. Monitored (M) turtles were studied by the hidden observer in addition to the team leader and volunteers, who counted the number of eggs during egg laying by illuminating the egg chamber with a red light introduced to one side of the nest chamber. Turtles from the 'tourist' $(\mathrm{T})$ treatment were observed by the hidden observer and by a group of 8-16 tourists and a tour guide. During these observations, the guide followed the same protocol as the team leader with ' $\mathrm{M}$ ' turtles, although illumination of the egg chamber was brighter. During tourist visits, the tour guide conversed with the tourists in a low voice, explaining each nesting stage and answering any questions, while tourists remained behind the turtle, either kneeling or lying down on the sand. Occasionally, the turtle began the descent to the sea while the tourists were in her path, in which case the tourists were asked to move slowly to the side, leaving the path clear for the turtle, who passed in front of them.

To assess the influence of turtle watching on clutch size and female nest-site fidelity, a $5 \mathrm{~km}$ stretch of João Barrosa beach (Fig. 2) was monitored every night from 20:00 to 05:00 $\mathrm{h}$ from mid-June to midOctober in 3 years (2013-2015). This stretch of the beach has supported high nesting density and high numbers of turtle-watching visits since 2006. These field surveys were conducted daily by $2-4$ teams, each led by an experienced observer and 2-3 volunteers. During the 3 years of this study, a total of 2437 turtle identifications (862 in 2013, 711 in 2014 and 864 to 2015), corresponding to 1159 individuals, were recorded. Of these, 187 turtles were first observed during a turtle-watching visit and were therefore considered as ' $\mathrm{T}$ ' turtles (56 of 463 in 2013, 46 of 325 in 2014 and 85 of 371 in 2015). The rest of the individuals were considered as controls. Clutch size was counted for females encountered before egg laying commenced. While clutch size varies according to female condition, female size and environmental conditions (Broderick et al. 2003, Price et al. 2004, Cardona et al. 2014), we collected these data to cautiously assess any differences in reproductive output in relation to observed turtle-watching activity which might indicate that females may abort oviposition in the presence of tourists and hence lay smaller clutch sizes. The remaining data were recorded after egg laying in order to minimize disturbance to the females. Neophyte turtles were passive integrated transponder (PIT)-tagged in the right flipper using AVID Friendchip PITs, and tags were read using AVID Minitracker III scanners. Curved carapace length (CCL) was measured to the nearest $0.5 \mathrm{~mm}$, and the date, time and location (using a Garmin Etrex GPS) were recorded for each individual.

Many turtle species and populations demonstrate high site fidelity within a nesting season, often nesting within a few kilometers of the first nest laid in the season in subsequent nesting events (Tucker 2010, Matos et al. 2012). We therefore investigated whether turtles observed by tourists would display reduced nest-site fidelity within a season, potentially nesting at sites farther away from the site where they were observed by tourists, compared to control females. Within-season nest-site fidelity was estimated for each female as the number of subsequent nesting events recorded on the same $5 \mathrm{~km}$ stretch of beach within the same nesting season after the initial identification. The re-nesting rate for ' $\mathrm{T}$ ' turtles was calculated from the first observation conducted in the presence of tourists. To maximize the likelihood of recaptures, this study only used turtles (of both treatments) that were first observed before the end of August.

\subsection{Data analysis}

All statistical analyses were performed using SPSS Statistics 24.0 (IBM) software. Data were tested for normality and homogeneity of variance using Shapiro-Wilk's and Levene's tests respectively. All data met these assumptions and were thus analyzed using parametric techniques. Chi-squared analysis was performed to compare the frequency of hunted females between beach sectors with different levels of turtle poaching. These data were analyzed by beach 
and by PA separately (Fig. 2). Sensitivity analysis was performed prior to this analysis of nesting behavior due to the low sample size of females observed during turtle watch visits. Differences in clutch size were analyzed with ANCOVA, where female size (CCL) was included as a covariate. To ensure independence, only the clutch size data from the first nest of each studied female was included in our analyses. To evaluate the influence of turtlewatching tours on nest abundance, we compared the number (as relative percentage) of nests laid on the sections of João Barrosa beach that experienced tourist visits with that across the wider beach without tourist visits. This analysis was performed for the periods 2007-2011 and 2012-2016 separately in order to permit a comparison between results found in both periods. We used percentages and not the raw number of nests due to the variation in the number of nests laid between each nesting season, although the percentage distribution of nests laid on each beach across the island is very stable in this rookery (Marco et al. 2012). Fisher's exact tests were used in the analysis of the effect of turtle watching on nest-site fidelity. Treatment differences in the duration of each of the different phases of the nesting process were investigated using ANOVA.

\section{RESULTS}

\subsection{Turtle watching}

A mean of 8.3 tour operators (range: $7-10$ ) and 56.3 taxi drivers (range: $46-75$ ) per year obtained permits to conduct turtle-watching tours during 2013-2016, carrying a mean of 4942 tourists annually to the

Table 1. Beach length, regulations to and frequency of turtle watching on the main nesting beaches of Boa Vista (Cabo Verde). Dashes: data not registered; blank cells: 0 tourists

\begin{tabular}{|lccccccc|}
\hline Beach & $\begin{array}{c}\text { Length } \\
(\mathrm{km})\end{array}$ & $\begin{array}{c}\text { Daily } \\
\text { tourist } \\
\text { limit }\end{array}$ & $\begin{array}{c}\text { No. } \\
\text { of } \\
\text { groups }\end{array}$ & $\begin{array}{c}\text { No. of } \\
2013\end{array}$ & 2014 & 2015 & 2016 \\
\hline Ponta Pesqueiro & 0.5 & 8 & 1 & 496 & 361 & 126 & 85 \\
João Barrosa & 3 & 48 & 6 & 2921 & 2355 & 2205 & 2161 \\
Ponte Cosme & 1.0 & 32 & 2 & 770 & 1337 & 1238 & 1166 \\
Ervatão & 0.6 & 16 & 2 & 687 & 592 & 643 & 543 \\
Flor and Figura & 1.0 & 16 & 2 & 566 & 376 & 284 & 20 \\
Boa Esperança & 1.6 & 8 & 1 & 100 & 223 & - & \\
Varandinha & 1.29 & 20 & 2 & - & - & - & \\
Not identified & & & & 147 & & 163 & 305 \\
Total & & 132 & 16 & 5687 & 5244 & 4559 & 4280 \\
\hline
\end{tabular}

beaches of Boa Vista (Table 1). This corresponds to $<8 \%$ of all tourists who stayed on the island during the nesting period (July to September). The price of the visit ranged from EUR 25 to 85 (mean: around EUR 50) per person. The annual number of tours decreased across the study period, probably due to changes in nesting abundance (Table 1). Most turtle visits were conducted in the STNR (Curral Velho, João Barrosa, Ponta Cosme and Ervatão beaches) and some in the NNP (Nho Martin, Flor and Figura beaches) and BENR (Boa Esperança beach) (Fig. 2). Data indicate that from 2013 to 2016, authorized turtle watching on Boa Vista generated a mean annual direct income of >USD 289000 into the island and the direct creation of $>250$ jobs, including guards, rangers, administrative staff, drivers and guides.

Almost half $(49.7 \%)$ of tours occurred between 21:00 and $22: 00 \mathrm{~h}$ and just over a third (34.5\%) between 22:00 and 23:00 h. The mean number of tourists per group was 15.2 (SD: 10.1, range: 10-28), and all groups watched turtles nesting on the beach.

\subsection{Nest abundance}

The nest distribution varied greatly across the island (Fig. 2), with the highest nest density in the southeast region of the island (within the STNR). This area supported an average of $21.0 \%$ of all nesting activities on Boa Vista and $30.2 \%$ of the STNR throughout the study period, with an average nest density of 15 nests $\mathrm{km}^{-1} \mathrm{~d}^{-1}$ laid on beaches within this area. The spatial distribution of nests within this area varied similarly (Fig. 3), ranging from 2.1 to 28.9 nests $\mathrm{km}^{-1} \mathrm{~d}^{-1}$. The daily number of nests laid within the region ranged from 1.8 to 21.4.

On average, João Barrosa beach specifically supported $48.2 \%$ (SD: 3.17, range: $44.9-51.4$ ) of the turtlewatching trips on Boa Vista during the study period. Mean annual nest abundance on the sections of João Barrosa with turtle-watching tours in 20072011 was 1632.6 nests (range: 6422803), representing $58.0 \%$ of nests across the entire beach (range: 50.164.9). Mean annual nest abundance on the same beach sectors in 2012-2016 was 1697.8 (range: 762-3115), representing $61.6 \%$ (range: $56.2-67.9$ ) of all nests across the entire beach. There was a positive but non-significant correlation of the percentage of nests in 


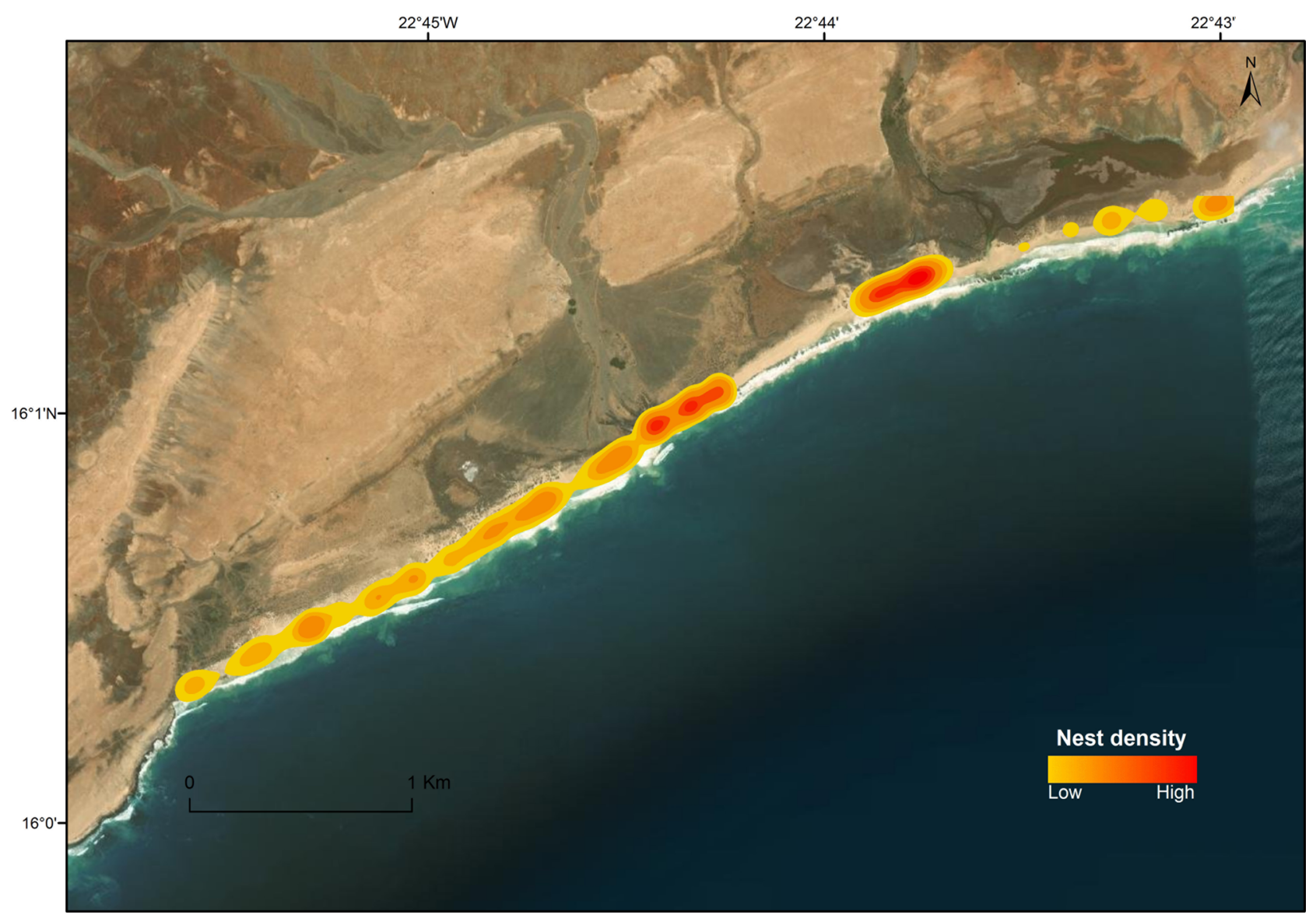

Fig. 3. Spatial distribution of loggerhead turtle nests on João Barrosa beach within the Turtle Natural Reserve on Boa Vista during 2013

the turtle watching zones across time from 2007 to $2016(\mathrm{r}=0.605, \mathrm{p}=0.063)$.

\subsection{Poaching of females}

Poaching of females was recorded on all beaches of Boa Vista and within all PAs (Fig. 2) but at different rates. The east (1 beach of the PNN) and southeast (4 beaches of the STNR) areas of the island showed the highest hunting pressure (Table 2). Nesting females were slaughtered on the beach or, increasingly, were transported live to locations elsewhere to avoid the poachers being caught.

The number of hunted turtles on the beaches of Boa Vista decreased significantly throughout the study period (Fig. 4) and was strongly nega- tively correlated with the number of tourists engaged in turtle-watching activities $\left(\mathrm{r}^{2}=0.755, \mathrm{p}>\right.$ 0.0001). The number of hunted females within the 3 PAs deviated significantly from expected frequen-

Table 2. Turtle-watching activity, loggerhead turtle nest abundance and recorded numbers of poached females on key nesting beaches on Boa Vista from 2013 to 2016 . High: $\geq 1$ tour night ${ }^{-1}$; medium: $\geq 1$ tour $\mathrm{wk}^{-1}$; low: $<1$ tour $\mathrm{wk}^{-1}$; none: very occasional tours

\begin{tabular}{|lcccc|}
\hline Beach & $\begin{array}{c}\text { Turtle } \\
\text { watching }\end{array}$ & $\begin{array}{c}\text { No. of } \\
\text { nests }\end{array}$ & $\begin{array}{c}\text { Observed } \\
\text { poaching events }\end{array}$ & $\begin{array}{c}\text { Impact on turtle } \\
\text { conservation }\end{array}$ \\
\hline João Barrosa & High & $>1000$ & $<5$ & Very positive \\
Ponta Cosme & High & $>1000$ & $<5$ & Very positive \\
Ervatao & High & $>1000$ & $<5$ & Very positive \\
Caletha & None & $>1000$ & $>20$ & Very negative \\
Ladjedo Teixeira & None & $>500$ & $>20$ & Very negative \\
Curralvelho & Low & $>500$ & $<10$ & Neutral \\
Ponta Pesquero & Medium & $>200$ & $<5$ & Positive \\
Carreto & None & $>500$ & $>20$ & Very negative \\
Praiona & None & $>500$ & $>20$ & Very negative \\
Nho Martin & Low & $>500$ & $>20$ & Very negative \\
\hline
\end{tabular}




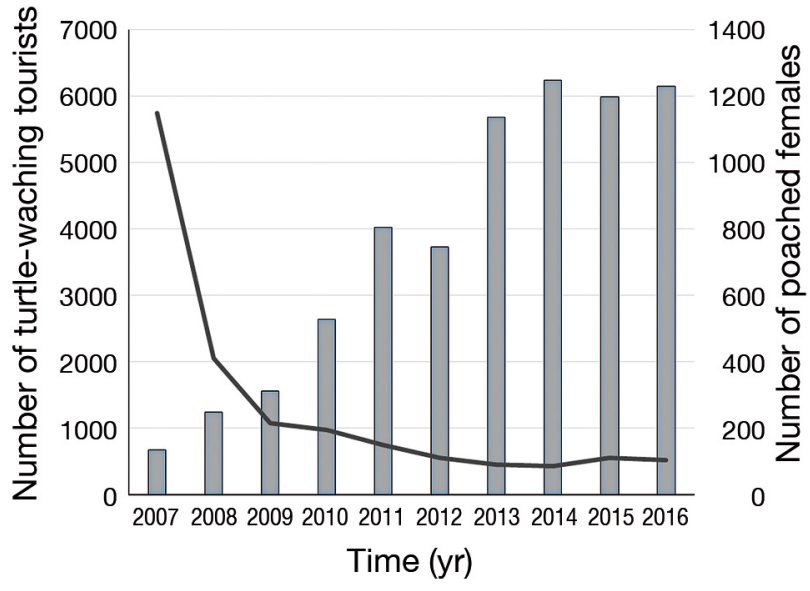

Fig. 4. Trend in the annual number of tourists that participated in authorized turtle-watching tours (left $y$-axis and grey bars) and the number of loggerhead turtle females poached on the beach (right $y$-axis and black line) on Boa Vista. Source: Office of Protected Areas of Boa Vista (Cabo Verde)

cies for each of the 3 years of the study $\left(2014: \chi^{2}=\right.$ 45.61, $\mathrm{p}<0.0001 ; 2015: \chi^{2}=18.61, \mathrm{p}<0.0001 ; 2016$ : $\left.\chi^{2}=61.79, \mathrm{p}<0.0001\right)$. The lowest rate of turtle hunting over the 3 years was observed within the STNR, which supported a high level of turtle watching. Moreover, all hunting incidents recorded in this area occurred on isolated beaches with no turtle watching (Table 2). In contrast, the PNN showed the highest level of turtle hunting and a very low level of turtle watching.

\subsection{Nesting behavior, clutch size and nest-site fidelity}

The duration of 5 of the 6 nesting phases was similar in both watched and control turtles, including the ascent (ANOVA: $F=0.128, \mathrm{df}=2,21, \mathrm{p}=0.881$ ), digging (ANOVA: $F=0.854, \mathrm{df}=2,38, \mathrm{p}=0.434$ ), egg laying (ANOVA: $F=0.796, \mathrm{df}=2,60, \mathrm{p}=0.456$ ), nest covering (ANOVA: $F=0.886, \mathrm{df}=2,72, \mathrm{p}=0.417$ ) and descent (ANOVA: $F=0.251, \mathrm{df}=2,63, \mathrm{p}=0.779$ ) phases. Only the duration of the camouflage phase showed a significant treatment effect (ANOVA: $F=3.283$, df $=$ $2,73, p=0.043$ ), with Tukey post hoc testing indicating that nest camouflaging in ' $\mathrm{T}$ ' females observed by tourists was significantly shorter $(p=0.038)$ than in control females, lasting on average $337 \mathrm{~s} \mathrm{(38 \% )} \mathrm{less}$ than controls (Fig. 5).

Results of ANCOVA with female CCL included as a covariate $(n=503)$ indicated that mean clutch size was similar between females watched by tourists and control females across the 3 years of the study (ANCOVA: $F=0.921, \mathrm{df}=5,1,2, \mathrm{p}=0.467$ ) (Table 3 ).

Of the 1159 females for which nest-site fidelity on João Barrosa beach was calculated, 463 females were observed in 2013, 325 in 2014 and 371 in 2015. Across all years, $36.8 \%$ of control females and $43.8 \%$ of females watched by tourists renested during the same nesting season. There was no significant treatment effect on re-nesting rates, either across all years or for any year individually (Table 4).

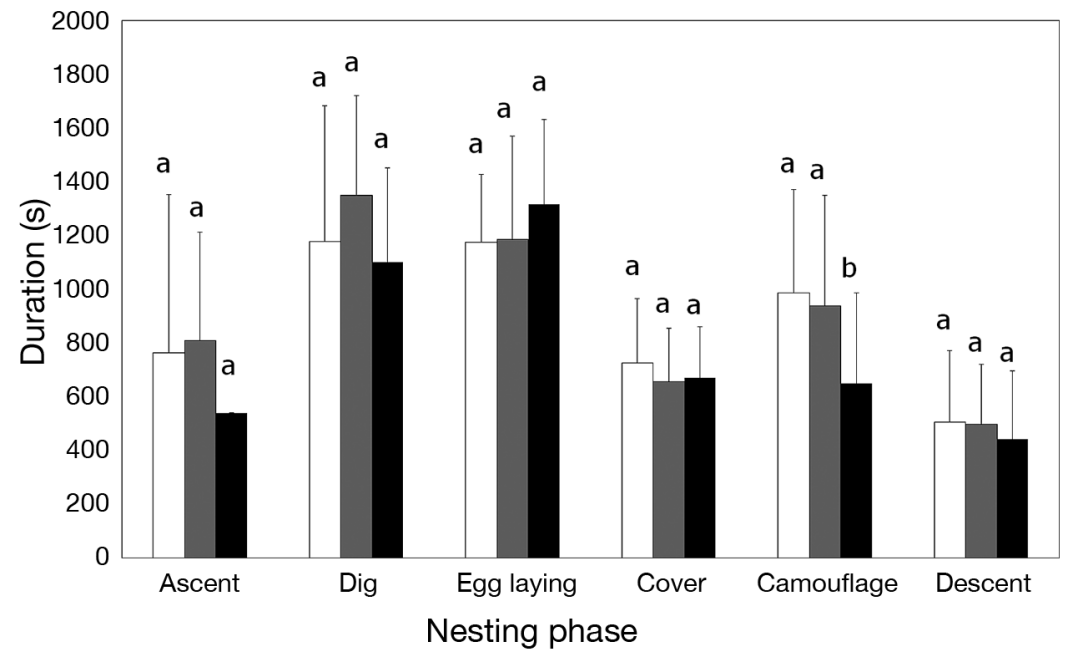

Fig. 5. Influence of turtle watching on the duration of each nesting stage of female loggerhead turtles on Boa Vista during 2016. White: control females; grey: turtles monitored by a researcher/volunteers; black: turtles watched by tourists. Error bars: SD. Different letters indicate statistically significant differences between groups $(\mathrm{p}<0.05)$

\section{DISCUSSION}

Turtle watching in Cabo Verde began with a pilot project in 2003 to initiate its promotion and facilitate capacity building and implementation of good practice on the island. Currently, Boa Vista has a population of around 10000 people with a mean monthly salary of USD 200 (INE 2019), and turtle-watching tourism creates significant revenue. Over a period of just 3 mo (July to September), turtlewatching activities directly generate >USD 280000 for the island, while total income from tourism including a full day of tourist activities plus turtle watching is estimated at USD 1280000 (INE 2019). Turtle-watching tourism is therefore a key business on 
Table 3. Influence of turtle-watching tourism on loggerhead turtle clutch size (no. of eggs, mean \pm SD) on João Barrosa beach, Boa Vista. Data presented by month due to the significant variation of clutch size throughout the season. n: sample size (no. of turtles); empty cells: no data available

\begin{tabular}{|c|c|c|c|c|c|c|c|c|}
\hline & \multicolumn{2}{|c|}{ July } & \multicolumn{2}{|c|}{$\longrightarrow$ August } & \multicolumn{2}{|c|}{ September -} & \multicolumn{2}{|c|}{ Total } \\
\hline & Tourism & Control & Tourism & Control & Tourism & Control & Tourism & Control \\
\hline 2013 & $\begin{array}{c}91.5 \pm 17.2 \\
(\mathrm{n}=21)\end{array}$ & $\begin{array}{c}86.5 \pm 15.9 \\
(\mathrm{n}=119)\end{array}$ & $\begin{array}{c}86.2 \pm 14.9 \\
(\mathrm{n}=17)\end{array}$ & $\begin{array}{c}87.4 \pm 17.9 \\
(\mathrm{n}=57)\end{array}$ & $\begin{array}{c}90.5 \pm 16.4 \\
(\mathrm{n}=2)\end{array}$ & $\begin{array}{c}90.7 \pm 16.6 \\
(\mathrm{n}=2)\end{array}$ & $\begin{array}{c}89.0 \pm 15.8 \\
(\mathrm{n}=40)\end{array}$ & $\begin{array}{c}86.8 \pm 15.9 \\
(\mathrm{n}=179)\end{array}$ \\
\hline 2014 & $\begin{array}{c}88.3 \pm 18.4 \\
(\mathrm{n}=13)\end{array}$ & $\begin{array}{c}89.0 \pm 16.8 \\
(\mathrm{n}=86)\end{array}$ & $\begin{array}{c}78.8 \pm 14.7 \\
(\mathrm{n}=19)\end{array}$ & $\begin{array}{c}85.7 \pm 17.6 \\
(\mathrm{n}=85)\end{array}$ & & & $\begin{array}{c}83.0 \pm 16.7 \\
(\mathrm{n}=32)\end{array}$ & $\begin{array}{c}87.3 \pm 17.2 \\
(\mathrm{n}=172)\end{array}$ \\
\hline 2015 & $\begin{array}{c}92.6 \pm 13.1 \\
(\mathrm{n}=23)\end{array}$ & $\begin{array}{c}89.9 \pm 16.6 \\
(\mathrm{n}=60)\end{array}$ & $\begin{array}{c}91.9 \pm 19.7 \\
(\mathrm{n}=35)\end{array}$ & $\begin{array}{c}87.2 \pm 14.2 \\
(\mathrm{n}=92)\end{array}$ & & & $\begin{array}{c}92.0 \pm 17.2 \\
(\mathrm{n}=58)\end{array}$ & $\begin{array}{c}88.3 \pm 15.2 \\
(\mathrm{n}=152)\end{array}$ \\
\hline
\end{tabular}

Table 4. Influence of turtle watching tours on the nest site fidelity of female loggerhead turtles that nested on the monitored $5 \mathrm{~km}$ stretch of beach of Joao Barrosa beach, Boa Vista, within a nest season. Significance $(\mathrm{p}<0.05)$ of the comparison of the percentage of re-nesters between Control and Tourism groups using Fisher's exact test

\begin{tabular}{|c|c|c|c|c|c|c|c|c|}
\hline & \multicolumn{2}{|c|}{$-2013-$} & \multicolumn{2}{|c|}{$-2014-$} & \multicolumn{2}{|c|}{$-2015-$} & \multicolumn{2}{|c|}{$\ldots$ Total } \\
\hline & Control & Tourism & Control & Tourism & Control & Tourism & Control & Tourism \\
\hline All females & 407 & 56 & 279 & 46 & 286 & 85 & 972 & 187 \\
\hline Re-nesters (\%) & 32.2 & 42.9 & 39.1 & 47.8 & 42.4 & 41.3 & 36.8 & 43.8 \\
\hline $\begin{array}{l}\text { Mean no. of times each } \\
\text { female re-nested }\end{array}$ & 0.56 & 0.62 & 0.66 & 0.87 & 0.71 & 0.73 & 0.64 & 0.73 \\
\hline No. of re-nesters & 131 & 24 & 109 & 22 & 118 & 36 & 358 & 82 \\
\hline No. of non-re-nesters & 276 & 32 & 170 & 24 & 168 & 49 & 614 & 105 \\
\hline p-value & \multicolumn{2}{|c|}{0.131} & \multicolumn{2}{|c|}{0.330} & \multicolumn{2}{|c|}{0.901} & \multicolumn{2}{|c|}{0.071} \\
\hline
\end{tabular}

Boa Vista with the potential to expand further and facilitate the economic development of local communities. Turtle watching is also conducted on Sal, another island of the archipelago with high demand for tourism (Taylor \& Cozens 2010), although the activity is not regulated and the income is unknown.

Income generated by wildlife-watching tourism globally is enormous (UNWTO 2020). With careful and proper planning, the industry is capable of generating both ecological and socio-economic benefits for a country. Whale watching, for example, generates $>$ USD 2.5 billion annually and provides approximately 19000 jobs around the world (CisnerosMontemayor et al. 2010), while in the Bahamas, manta-ray watching generates USD 140 million annually (O'Malley et al. 2013), and shark watching generates USD 78 million annually (Gallagher \& Hammerschlag 2011). Turtle watching generates approximately USD 509579 annually in Sri Lanka (Rathnayake 2016). The Tortuguero National Park in Costa Rica generates approximately USD 6.7 million annually through wildlife watching, while Projeto TAMAR in Brazil generates >USD 2 million including product sales (Troëng \& Drews 2004). In Mon Repos Conservation Park in Australia, total tourist expenditure per season is estimated at approximately USD
190 million (Wilson \& Tisdell 2001, Tisdell \& Wilson 2002).

Beyond the direct income from payment to watch turtles nesting on the beach, there are other associated benefits to turtle conservation. Turtle-watching tourism may facilitate and encourage participation in turtle conservation, by both locals and visiting tourists (Tisdell \& Wilson 2001, Troëng \& Drews 2004), and increases education and awareness (Tisdell \& Wilson 2005, Smith et al. 2019). The benefits of tourists engaging in turtle watching are not limited to improving understanding of the biology or behavior of sea turtles, but also include increasing conservation-focused knowledge that promotes longer-term awareness and efforts by tourists to benefit sea turtles in different ways (Smith et al. 2019). The simple act of observing nesting activity or releasing hatchlings into the sea can foster a greater sense of the importance of wider biodiversity and marine life. In some cases, however, the income generated from wildlife watching does not benefit conservation or sustainable development of local communities (Krüger 2005).

The present study demonstrates how turtle watching can directly protect natural resources. On Boa Vista, where $>60 \%$ of all loggerhead nesting activity 
in the Eastern Atlantic occurs, beaches with the highest level of turtle watching were subject to almost no hunting. Beaches with high nesting densities but little or no turtle watching, in contrast, suffer intense hunting pressure. Hunting of sea turtles by local communities on Boa Vista for meat is one of the main threats to the Cabo Verde loggerhead population (Casale \& Marco 2015). In 2007, around 1200 nesting females were hunted on unprotected beaches on Boa Vista, corresponding to $45 \%$ of all females that nested on the island that year (Marco et al. 2012). Since joint initiatives were launched in 2007 to increase local awareness of the issue, with beach patrols by volunteers and soldiers, alongside the development of turtle watching in Cabo Verde (Fig. 4), the mortality rate due to poaching has decreased considerably, falling to $18 \%$ of nesting females in 2008, 5\% in 2009 and $10 \%$ in 2010 (Fig. 4). The salaries and employment generated for local communities by this emerging industry sector are important, and many hunters and their relatives now receive important income from tourism, reducing hunting pressure on both sea turtles and other wildlife. While overall hunting levels on the island are still relatively high compared to what is sustainable, hunting behavior has changed since the increased prevalence of tourists on the beaches at night. Hunters likely avoid beaches visited by tourists, preferring to hunt on non-visited beaches to avoid interfering with the economic activities of neighbors, friends or relatives who are involved in turtle watching. The creation of turtle nesting sanctuaries where tourist visits are prohibited may therefore not necessarily favor turtle protection if hunting is consequently displaced to these areas. A responsible, well-conducted turtlewatching program could therefore be a very important direct tool to reduce the levels of turtle poaching on the island.

In many regions, regulations for wildlife watching of protected species are very strict (Kessler \& Harcourt 2013, Schofield et al. 2015), given the potential for serious adverse effects on such species and their habitats if rules and standards of conduct are violated (Kessler \& Harcourt 2013). Several cases of impacts to the environment, the behavior of observed animals, their stress level, injury and even indirect mortality have been documented (Orams 1997, Constantine et al. 2004, Lusseau 2004, Stewart et al. 2005, Semeniuk et al. 2009, Schofield et al. 2015). Our study presents important information that can contribute towards a robust risk assessment of the potential impacts of turtle watching on nesting females.

\subsection{Nesting behavior}

We provide evidence that turtle watching alters the behavior of females during the nest-camouflaging phase of the nesting process, but has no detectable impact on all other stages. Potential alteration of nesting behavior due to elevated stress levels in females in the presence of tourists may prevent or hinder the nesting process, potentially causing incomplete or poor oviposition or nest camouflage, subsequently decreasing hatching success (Broderick \& Godley 1999). Our results indicate that turtle watching did not affect nest construction, oviposition or the nest-covering phase, although there was a significant reduction in the duration of the nest-camouflage phase in the presence of tourists. When the female was tagged after oviposition by a small team of experienced researchers/volunteers, no alteration of any nesting phase was observed.

The presence of tourists during oviposition did not affect the duration or the number of eggs laid. Various factors influence reproductive output in marine turtles, including female condition, female body size and the availability of food resources (Broderick et al. 2003, Price et al. 2004), and are perhaps stronger drivers of clutch size than tourist presence. It may therefore be reasonably expected that only if the presence of tourists during oviposition affected female body condition and fecundity, which could be considered unlikely, would a difference be observed. Furthermore, such an impact of tourist presence may only become evident after long-term exposure, rather than within the time scale of the present study. The lack of change in nesting duration may be due to the production of anti-stress hormones in nesting females (Carr \& Hirth 1962, Ehrenfeld 1979). Past studies have shown endocrinal mechanisms to regulate the stress response during breeding and nesting in females (Jessop et al. 2004), maintaining reproductive ability and promoting successful reproduction under otherwise stressful conditions outside of the relative safety of the marine environment. This insensitivity to stressful conditions likely peaks during oviposition (Hendrickson 1958), when females are insensitive to human interaction/presence, before subsequently waning during the latter stages of the nesting process, including during nest camouflaging. Hence, our results indicate a reduction in the time spent on nest camouflaging in the presence of tourists, once this state of insensitivity wanes.

The observed reduction in time spent on nest camouflaging may increase the risk of nest predation during incubation, reducing hatching success. 
Predation by ghost crabs is a major threat to turtle nests in Cabo Verde (Marco et al. 2015), and any increase has implications for the conservation of this endangered population. The mechanisms behind this observed behavioral change should be fully evaluated and protocols and regulations for turtle watching should be revised as mitigation. A previous study on loggerhead turtles in Florida showed a similar reduction in the camouflage time due to turtle watching (Johnson et al. 1996), although the study monitored the nest until emergence and found no impact on embryonic survival. Even with no impact on incubation success, we recommend that best practice guidelines should ensure that tourists stay quiet and out of the visual field of the turtles during nest camouflaging and avoid blocking the way to the sea, allowing females to complete the full nesting process without disturbance. Since our results suggest that visual stimuli through the presence of tourists during the 'insensitive' phase of oviposition may elicit a delayed behavioral response during subsequent nesting stages, we recommend that restrictions on the behavior of tourists during oviposition should be maintained during the entire nesting process, until the female reaches the sea. Our observations of nesting events monitored by experienced staff, during which females are observed, tagged and measured during the covering and camouflaging process with no behavioral alterations, provide proof that a null impact of human presence on nesting behavior is certainly achievable. The behavior of tourists during visits should be regulated to also achieve null impacts on all phases of nesting, ensuring a sustainable and profitable turtle-watching industry.

\subsection{Nest-site fidelity}

Sea turtles demonstrate natal philopatry and repeatedly nest on the same beaches (Bowen et al. 1994, Monzón-Argüello et al. 2010, Reis et al. 2010, Carreras et al. 2011). This behavior has developed during the long evolutionary success of these vertebrates and any factor that alters nest-site fidelity may be considered as a serious threat for sea-turtle conservation. We investigated whether females that experience disturbance from tourists while nesting may relocate subsequent nesting attempts to another beach or beach sector. We did not detect evidence of an effect of turtle watching on the re-nesting rate of ' $\mathrm{T}$ ' females compared to controls, however. This may indicate either that females do not retain any mem- ory of tourist presence during previous nesting activities, or alternatively, females retain this information but with no influence on subsequent nest-site selection, demonstrating a lack of behavioral plasticity. Furthermore, nesting females may be unable to identify the exact location where tourists are present. While there is wide variation in the extent to which females return to the same nesting beaches, among both species and populations (Tucker 2010, Oliveira 2019), we did not detect evidence of an impact of turtle watching during the nesting process on subsequent nest-site fidelity within the nesting season. A better understanding of the mechanisms behind plasticity in site selection and longer-term effects of tourist visits on nesting behavior could better inform future management of turtle watching, yet our results indicate that females watched by tourists came back to nest in the same beach sector and that nest abundance was not reduced on beaches used for turtle watching.

\section{CONCLUSIONS}

Turtle watching as a tourism industry can be a key economic activity supporting the sustainable development of developing countries. In coastal areas, this activity can generate employment while driving a significant decrease in turtle hunting on the beaches where turtle watching takes place. Our study reveals no evidence of long-term changes in nest abundance on beaches used for turtle watching. Nor does turtle watching alter the number of eggs laid or the nestsite selection in nesting loggerhead females. The only apparent impact that we report is a reduction in time spent on nest-camouflaging behavior that could potentially affect nesting success through altering predation rates. However, this impact can be easily mitigated by revising and adapting the protocols of turtle watching. Recommended turtle-watching practices include legal regulation, supervision and control of the activity by experienced guards, and redirecting a portion of the generated income for the sustainable development of local communities. Based on the results of this study, we suggest that management guidelines incorporate requirements for turtle-watching groups to retreat from the immediate vicinity of a female once oviposition is complete, to allow for the nest-camouflaging phase to be completed fully and consequently reduce detection by predators. Future work may seek to validate whether this recommendation does result in longer nest-camouflaging phases. 
Acknowledgements. Thanks to all the staff and volunteers of the NGO BIOS.CV for their help in the field studies. Special thanks to Marina N'Deye from the Office of Protected Areas of Boa Vista and to Pedro López from Naturalia for their collaboration with this study. This research was funded by the Marine Turtle Conservation Fund of the US Fish and Wildlife Service and the Spanish Research Council (CSIC).

\section{LITERATURE CITED}

Balmford A, Green JMH, Anderson M, Beresford J and others (2015) Walk on the wild side: estimating the global magnitude of visits to protected areas. PLOS Biol 13:e1002074

Bowen BW, Kamezaki N, Limpus CJ, Hughes GR, Meylan AB, Avise JC (1994) Global phylogeography of the loggerhead turtle (Caretta caretta) as indicated by mitochondrial-DNA haplotypes. Evolution 48:1820-1828

Broderick AC, Godley BJ (1999) Effect of tagging marine turtles on nesting behavior and reproductive success. Anim Behav 58:587-591

Broderick AC, Glen F, Godley BJ, Hays GC (2003) Variation in reproductive output of marine turtles. J Exp Mar Biol Ecol 288:95-109

Cardona L, Clusa M, Eder E, Demetropoulos A and others (2014) Distribution patterns and foraging ground productivity determine clutch size in Mediterranean loggerhead turtles. Mar Ecol Prog Ser 497:229-241

Carr A, Hirth H (1962) The ecology and migrations of sea turtles: 5. Comparative features of isolated green turtle colonies. Am Mus Novit no. 2091

* Carreras C, Pascual M, Cardona L, Marco A and others (2011) Living together but remaining apart: Atlantic and Mediterranean loggerhead sea turtles (Caretta caretta) in shared feeding grounds. J Hered 102:666-677

* Casale P, Marco A (2015) Caretta caretta (North East Atlantic subpopulation). IUCN Red List of Threatened Species 2015:e.T83776383A83776554. https://dx.doi.org/ 10.2305/IUCN.UK.2015-4.RLTS.T83776383A83776554.en

* Cisneros-Montemayor AM, Sumaila UR, Kaschner K, Pauly D (2010) The global potential for whale watching. Mar Policy 34:1273-1278

Constantine R, Brunton DH, Dennis T (2004) Dolphinwatching tour boats change bottlenose dolphin (Tursiops truncatus) behavior. Biol Conserv 117:299-307

Downie JR, Muir H, Dinwoodie M, McKinnon L, Dodds L, Cascarina M (2003) Turtle watch: a collaboration between the University of Glasgow and RAF Akrotiri to protect marine turtles in Cyprus. Testudo 5:14-21

Ehrenfeld DW (1979) Behaviour associated with nesting. In: Harless M, Morlock $\mathrm{H}$ (eds) Turtles: perspectives and research. John Wiley \& Sons, New York, NY, p 417-434

Fennell DA (2006) Tourism ethics. Channel View Publications, Bristol

*Gallagher AJ, Hammerschlag N (2011) Global shark currency: the distribution, frequency, and economic value of shark ecotourism. Curr Issues Tour 14:797-812

Godfrey MH, Drif OD (2001) Guest editorial: developing sea turtle ecotourism in French Guiana: perils and practicalities. Mar Turtle Newsl 91:1-4

Hearne RR, Salinas ZM (2002) The use of choice experiments in the analysis of tourist preferences for ecotourism development in Costa Rica. J Environ Manage 65:153-163
Hendrickson JR (1958) The green sea turtle, Chelonia mydas (Linn.) in Malaya and Sarawak. Proc Zool Soc Lond 130:455-535

*Howell EA, Hoover A, Benson SR, Bailey H, Polovina JJ, Seminoff JA, Dutton PH (2015) Enhancing the Turtle Watch product for leatherback sea turtles, a dynamic habitat model for ecosystem-based management. Fish Oceanogr 24:57-68

*Humber F, Godley BJ, Broderick AC (2014) So excellent a fishe: a global overview of legal marine turtle fisheries. Divers Distrib 20:579-590

INE (Instituto Nacional de Estatística) (2019) Índice de preço turístico. Síntese dos resultados, IV Trimestre 2018. INE, Praia

IUCN (2020) The IUCN Red List of Threatened Species. https://www.iucnredlist.org/search?query=Sea \%20Turtles $\&$ searchType=species (accessed 20 Mar 2020)

Jessop T, Sumner J, Lance V, Limpus C (2004) Reproduction in shark-attacked sea turtles is supported by stressreduction mechanisms. Proc R Soc B 271:S91-S94

Johnson SA, Bjorndal KA, Bolten AB (1996) Effects of organized turtle watches on loggerhead (Caretta caretta) nesting behavior and hatchling production in Florida. Conserv Biol 10:570-577

Kessler M, Harcourt R (2013) Whale watching regulation compliance trends and the implications for management off Sydney, Australia. Mar Policy 42:14-19

Krüger O (2005) The role of ecotourism in conservation: panacea or Pandora's box? Biodivers Conserv 14:579-600

* Landry MS, Taggart CT (2010) 'Turtle watching' conservation guidelines: green turtle (Chelonia mydas) tourism in nearshore coastal environments. Biodivers Conserv 19: 305-312

Loureiro NS, Torrão MMF (2008) Homens e tartarugas marinhas. Seis séculos de história e histórias nas ilhas de Cabo Verde. An Hist Alem Mar 9:37-78

Lusseau D (2004) The hidden cost of tourism: detecting long-term effects of tourism using behavioral information. Ecol Soc 9:2-16

Malik MI, Bhat MS (2015) Sustainability of tourism development in Kashmir. Is paradise lost? Tour Manage Perspect 16:11-21

Marco A, Abella-Pérez E, Liria-Loza A, Martins S and others (2012) Abundance and exploitation of loggerhead turtles breeding in the Boa Vista island of Cape Verde, their only substantial rookery in the Eastern Atlantic. Anim Conserv 15:351-360

* Marco A, da Graça J, García-Cerdá R, Abella-Pérez E, Freitas R (2015) Patterns and intensity of ghost crab predation on the nests of an important endangered loggerhead turtle population. J Exp Mar Biol Ecol 468:74-82

Marcovaldi MA, Marcovaldi GG (1999) Marine turtles of Brazil: the history and structure of Projeto TAMARIBAMA. Biol Conserv 91:35-41

Martins S, Rocha F, Rodrigues E, Araújo-Lopes S, AbellaPérez E, Loureiro NS, Marco A (2015) The use of sea turtles in traditional medicine in the Cape Verde Archipelago, West Africa. Afr Sea Turtle Newsl 4:12-15

*Matos L, Silva AC, Castilhos JC, Weber MI, Soares LS, Vicente L (2012) Strong site fidelity and longer internesting interval for solitary nesting olive ridley sea turtles in Brazil. Mar Biol 159:1011-1019

*Meletis ZA, Harrison EC (2010) Tourists and turtles: searching for a balance in Tortuguero, Costa Rica. Conserv Soc 8:26-43 
Monzón-Argüello C, Rico C, Naro-Maciel E, Varo-Cruz N, López P, Marco A, López-Jurado LF (2010) Population structure and conservation implications for the loggerhead sea turtle of the Cape Verde Islands. Conserv Genet 11:1871-1884

Oliveira ASRD (2019) How high and low nesting season densities affect the patterns of nest site preferences and nest site fidelity of Caretta caretta, on Maio island, Cape Verde. Master's thesis, University of Lisbon

O'Malley MP, Lee-Brooks K, Medd HB (2013) The global economic impact of manta ray watching tourism. PLOS ONE 8:e65051

Orams MB (1997) Historical accounts of human-dolphin interaction and recent developments in wild dolphin based tourism in Australasia. Tour Manage 18:317-326

Papafitsoros K, Panagopoulou A, Schofield G (2020) Social media reveals consistently disproportionate tourism pressure on a threatened marine vertebrate. Anim Conserv (in press), doi:10.1111/acv.12656

Parsons ECM, Warburton CA, Woods-Ballard A, Hughes A, Johnston P (2003) The value of conserving whales: the impacts of cetacean-related tourism on the economy of rural West Scotland. Aquat Conserv 13:397-415

Pegas FV, Stronza A (2010) Ecotourism and sea turtle harvesting in a fishing village of Bahia, Brazil. Conserv Soc 8:15-25

Poland RHC, Hall GB, Smith M (1996) Turtles and tourists: a hands-on experience of conservation for sixth formers from King's College, Taunton, on the Ionian Island of Zakynthos. J Biol Educ 30:120-128

Price ER, Wallace BP, Reina RD, Spotila JR, Paladino FV, Piedra R, Vélez E (2004) Size, growth, and reproductive output of adult female leatherback turtles Dermochelys coriacea. Endang Species Res 1:41-48

Rathnayake RMW (2016) 'Turtle watching': a strategy for endangered marine turtle conservation through community participation in Sri Lanka. Ocean Coast Manage 119: 199-207

Reis EC, Soares LS, Vargas SM, Santos FR and others (2010) Genetic composition, population structure and phylogeography of the loggerhead sea turtle: colonization hypothesis for the Brazilian rookeries. Conserv Genet 11: 1467-1477

Santarém F, Paiva F (2015) Conserving desert biodiversity through ecotourism. Tour Manage Perspect 16:176-178

Schofield G, Scott R, Katselidis KA, Mazaris AD, Hays GC (2015) Quantifying wildlife-watching ecotourism intensity on an endangered marine vertebrate. Anim Conserv 18:517-528

Semeniuk CAD, Bourgeon S, Smith SL, Rothley KD (2009)

Editorial responsibility: Paolo Casale,

Pisa, Italy

Reviewed by: 3 anonymous referees
Hematological differences between stingrays at tourist and non-visited sites suggest physiological costs of wildlife tourism. Biol Conserv 142:1818-1829

N Smith JR, Witherington B, Heimlich JE, Lindborg RJ, Neidhardt E, Savage A (2019) Public sea turtle watches serve as effective environmental education. Environ Educ Res 25:292-308

Stewart EJ, Draper D, Johnston ME (2005) A review of tourism research in the Polar Regions. Arctic 58:383-394

Taylor H, Cozens J (2010) The effects of tourism, beachfront development and increased light pollution on nesting loggerhead turtles Caretta caretta (Linnaeus, 1758) on Sal, Cape Verde Islands. Zool Caboverd 1:100-111

Tisdell C, Wilson C (2001) Wildlife-based tourism and increased support for nature conservation financially and otherwise: evidence from sea turtle ecotourism at Mon Repos. Tour Econ 7:233-249

Tisdell C, Wilson C (2002) Ecotourism for the survival of sea turtles and other wildlife. Biodivers Conserv 11: 1521-1538

Tisdell C, Wilson C (2005) Perceived impacts of ecotourism on environmental learning and conservation: turtle watching as a case study. Environ Dev Sustain 7:291-302

Topelko KN, Dearden P (2005) The shark watching industry and its potential contribution to shark conservation. J Ecotour 4:108-128

Troëng S, Drews C (2004) Money talks. Economic aspects of marine turtle use and conservation. WWF International, Gland

* Tucker AD (2010) Nest site fidelity and clutch frequency of loggerhead turtles are better elucidated by satellite telemetry than by nocturnal tagging efforts: implications for stock estimation. J Exp Mar Biol Ecol 383:48-55

*UNWTO (World Tourism Organization) (2020) World tourism barometer, Vol 18. https://www.e-unwto.org/loi/ wtobarometereng? expanded=d2020.v18 (accessed 20 April 2020)

Wallace BP, DiMatteo AD, Bolten AB, Chaloupka MY and others (2011) Global conservation priorities for marine turtles. PLOS ONE 6:e24510

*Weaver D (1999) Magnitude of ecotourism in Costa Rica and Kenya. Ann Tour Res 26:792-816

*Wilson C, Tisdell C (2001) Sea turtles as a non-consumptive tourism resource especially in Australia. Tour Manage 22:279-288

*Winterbach CW, Whitesell C, Somers MJ (2015) Wildlife abundance and diversity as indicators of tourism potential in Northern Botswana. PLOS ONE 10:e0135595

*Wunder S (2000) Ecotourism and economic incentives - an empirical approach. Ecol Econ 32:465-479

Submitted: June 182020

Accepted: April 19, 2021

Proofs received from author(s): July 8, 2021 